\title{
Effect of Potassium Gluconate on Potassium Transport of Rat Erythrocytes
}

\author{
Michihiko TSUJITANI*, Eiichiro OKABE and Haruo ITO** \\ Department of Pharmacology, Kanagawa Dental College. \\ 82 Inaoka-cho, Yokosuka 238, Japan
}

Accepted September 20, 1985

\begin{abstract}
Effect of potassium gluconate ( $\mathrm{K}-\mathrm{GL}$ ) on $\mathrm{K}^{+}$uptake of rat erythrocytes was investigated. $\mathrm{K}-\mathrm{GL}$ produced a significant increase in active $\mathrm{K}^{+}$transport of $\mathrm{Na}^{+}$-rich erythrocytes, while $\mathrm{Na}^{+}, \mathrm{K}^{+}$-ATPase activity of hemoglobin-free ghosts without a glycolytic system was unaffected. When the experiment was carried out in intact erythrocytes, K-GL increased the lactate production and ATP content, and it promoted the methemoglobin reduction rate. In $\mathrm{Na}^{+}$-rich erythrocytes, the glycolysis inhibitors which produced a marked reduction in lactate content abolished the $\mathrm{K}-\mathrm{GL}$-induced increase in $\mathrm{K}^{+}$and ATP content without affecting the $\mathrm{KCl}$ induced increase. These results suggest that $\mathrm{K}-\mathrm{GL}$ enhances $\mathrm{K}^{+}$transport of erythrocytes through acceleration of glycolytic process.
\end{abstract}

Hypokalemia is commonly seen as a consequence of the use of potent diuretic agents and mineralocorticoids (1-4). In the treatment of hypokalemia and in external dialysis, potassium salts are employed. Previously, we found that in the comparative studies on potassium chloride $(\mathrm{KCl})$, potassium aspartate (Asp-K) and potassium gluconate (K-GL) employed in clinics, oral or intravenous administration of K-GL most facilitated the improvement of hypokalemia and most extended the retention time of blood potassium level $(5,6)$. However, to date, the precise mechanism of the beneficial effect of $\mathrm{K}-\mathrm{GL}$ on hypokalemia is not understood well. It is of interest to determine how K-GL retains the blood $\mathrm{K}^{+}$level.

It is well known that red cells depend upon glycolysis for the maintenance of concentration gradients of sodium and potassium across the cell membranes $(7,8)$. Glycolysis is also needed to maintain the concentration of adenosine triphosphoric acid (ATP) and other phosphate esters (9), and ATP is sometimes regarded as the energy

* Present address: Research Center, Kayaku Co., Ltd., Ohi-machi, Iruma-gun, Saitama 354, Japan ** To whom correspondence should be addressed. transmitter between glycolysis and the active transport of cations.

With the implication of both $\mathrm{K}^{+}$transport into erythrocytes and glycolytic process, the present study was designed to test the effect of potassium salts (e.g., $\mathrm{KCl}, \mathrm{Asp}-\mathrm{K}$, and $\mathrm{K}$ $\mathrm{GL}$ ) on $\mathrm{K}^{+}$transport and to determine the relationship between the effect of K-GL and glycolysis in rat erythrocytes.

\section{Materials and Methods}

Preparation of erythrocytes and $\mathrm{Na}^{+}$-rich cells: Rat erythrocytes were prepared by allowing them to fill with $\mathrm{Na}^{+}$and empty of $\mathrm{K}^{+}$during storage at $2{ }^{\circ} \mathrm{C}$ in a sodium medium as previously described by Post and Jolly (10) with slight modifications. In brief, the heparinized arterial blood taken from male Wistar rats was centrifuged at 3,000 r.p.m. for $10 \mathrm{~min}$. The plasma and buffy layer coat were removed, and the packed erythrocytes were washed 3 times with an isotonic saline solution. Then the erythrocytes were allowed to stand at $2{ }^{\circ} \mathrm{C}$ for one week; and during this period, the cold storage sodium medium consisting of $110 \mathrm{mM} \mathrm{NaCl}, 25 \mathrm{mM} \mathrm{Na}_{2}$ $\mathrm{HPO}_{4}, 2 \mathrm{mM} \mathrm{HCl}, 2 \mathrm{mM} \mathrm{MgCl}, 3.7 \mathrm{mM}$ inosine, $10 \mathrm{mM}$ glucose, and $1 \mathrm{~g} / \mathrm{L}$ bovine albumin was renewed every 2 days to provide 
fresh substrate and to keep the $\mathrm{pH}$ at 7.4.

Uptake of $\mathrm{K}^{+}$into $\mathrm{Na}^{+}$-rich erythrocytes: $\mathrm{Na}^{+}$-rich erythrocytes were incubated in a medium ( $\mathrm{pH} 7.4$ ) with one of the potassium salts at $37^{\circ} \mathrm{C}$ for $60 \mathrm{~min}$, and the $\mathrm{K}^{+}$content within the cells was determined with an atomic absorption flamephotometer (Hitachi, 508). The composition of the incubation medium was similar to that of the storage sodium medium except that some of the $\mathrm{NaCl}$ in the sodium medium was replaced by various concentrations of $\mathrm{KCl}, \mathrm{Asp}-\mathrm{K}$ or $\mathrm{K}$ $\mathrm{GL}$ (2-32 $\mathrm{mM}$ as final $\mathrm{K}^{+}$concentrations). Before incubation, the cells were washed twice at room temperature with $30 \mathrm{ml}$ of the incubation medium. The hematocrit value of the incubated suspension was usually 2 to $5 \%$. After the incubation, the cells were washed 3 times with 50 to 100 volumes of a cold isotonic choline chloride solution at $2{ }^{\circ} \mathrm{C}$ by centrifugation and resuspension. The 0.1 $\mathrm{ml}$ samples of washed cells were hemolyzed by rapid mixing with 10 volumes of redistilled water. The $\mathrm{K}^{+}$content was determined by the ratio of the $\mathrm{K}^{+}$concentration to the hemoglobin concentration analyzed by the cyanmethemoglobin method (11).

Measurement of ATPase activity of hemoglobin-free erythrocyte ghosts: It is generally believed that the active $\mathrm{K}^{+}$transport into red cells depends on $\mathrm{Na}^{+}, \mathrm{K}^{+}$-ATPase in the cell membrane. Therefore, the effect of the potassium salts on the ATPase activity was studied using ghosts.

To prepare the ghost. $3.5 \mathrm{ml}$ of the rat erythrocytes was washed 3 times with saline by centrifugation and resuspension. The washed erythrocytes were hemolyzed by rapid mixing with $50 \mathrm{ml}$ of a $20 \mathrm{mOsm}$ hypotonic Veronal buffer solution ( $\mathrm{pH} 7.4)$. The hemolysate was centrifuged at $15,000 \times \mathrm{g}$ for $20 \mathrm{~min}$ and the sediment was washed with $50 \mathrm{~m}$ ! of the hypotonic buffer solution repeatedly 3 to 4 times until sedimented membranes became free of visible hemoglobin (12). Then they were suspended in the hypotonic buffer solution. The suspension was stored overnight at $4^{\circ} \mathrm{C}$ before the determination of the ATPase activity. An aliquot of the hemolysate $(0.1 \mathrm{ml})$ was mixed with $3 \mathrm{mM}$ ATP, $5 \mathrm{mM} \mathrm{MgCl}, 125-$ $145 \mathrm{mM} \mathrm{NaCl}, 1-20 \mathrm{mM}$ one of $\mathrm{KCl}$, Asp-K or K-GL, and $100 \mathrm{mM}$ Tris- $\mathrm{HCl}(\mathrm{pH} \mathrm{7.4)} \mathrm{in} \mathrm{a}$ total volume of $1 \mathrm{ml}$. The mixture was incubated for $30 \mathrm{~min}$ at $37^{\circ} \mathrm{C}$. ATPase activity was determined as the rate at which inorganic phosphate ( $\mathrm{Pi}$ ) was liberated during the incubation. Inorganic phosphate liberated was measured by the method of Dryer et al. (13). $\mathrm{Na}^{+}, \mathrm{K}^{+}$-ATPase activity was calculated as the difference between the ATPase activity in the presence and in the absence of $5 \times 10^{-4} \mathrm{M}$ ouabain, and this is presented as $\mu$ moles $\mathrm{Pi}$ per hr per mg protein. Protein concentration was determined according to the method of Lowry et al. (14).

Measurement of lactate production in intact erythrocytes: The cells were incubated in a medium (2 $\mathrm{ml}$ ) containing $112-119 \mathrm{mM}$ $\mathrm{NaCl}, 25 \mathrm{mM} \mathrm{Na}_{2} \mathrm{HPO}_{4}, 2 \mathrm{mM} \mathrm{HCl}, 10 \mathrm{mM}$ glucose and 1-8 $\mathrm{mM}$ one of $\mathrm{KCl}, \mathrm{Asp}-\mathrm{K}$ or $\mathrm{K}-\mathrm{GL}, \mathrm{pH} 7.4$, at $37^{\circ} \mathrm{C}$ for $60 \mathrm{~min}$. The hematocrit of this suspension medium was $10-20 \%$. The reaction was stopped with two volumes of $12 \%$ perchloric acid (PCA). After centrifugation, the supernatant was neutralized to $\mathrm{pH} 7.4$ with $5 \mathrm{mM} \mathrm{K}_{2} \mathrm{CO}_{3}$ and used for the determination of lactate according to the method of Minakami et al. (15).

Measurement of ATP content in intact erythrocytes: The intact erythrocytes were incubated in a medium containing $8 \mathrm{mM}$ one of the potassium salts, $102 \mathrm{mM} \mathrm{NaCl}, 25 \mathrm{mM}$ $\mathrm{Na}_{2} \mathrm{HPO}_{4}, 2 \mathrm{mM} \mathrm{HCl}$ and $10 \mathrm{mM}$ glucose, $\mathrm{pH} 7.4$, at $37^{\circ} \mathrm{C}$ for $60 \mathrm{~min}$. After the addition of 4 volumes of $0.6 \mathrm{~N}$ PCA, ATP was determined enzymatically (15).

Use of glycolysis inhibitors: The effect of each of the following agents was studied on potassium salts-induced changes in $\mathrm{K}^{+}$, lactate or ATP content in $\mathrm{Na}^{+}$-rich cells to clarify the relationship between $\mathrm{K}^{+}$transport and glycolysis. $\mathrm{Na}^{+}$-rich cells were preincubated with the inhibitor for $30 \mathrm{~min}$ before beginning the reaction.

1) Sodium fluoride (Wako Pure Chemical Co., $10 \mathrm{mM}$ ). This agent inhibits the enzyme systems acting between the phosphoglycerate-phosphopyruvate stages (16).

2) Monoiodoacetate (Wako Pure Chemical Co., $1 \mathrm{mM}$ ). This agent is known to stop the cycle between 3 -phosphoglyceraldehyde and 1,3-diphosphoglycerate (16).

3) Oxidized glutathione (Boehringer 
Mannheim, $1 \mathrm{mM}$ ), an effective inhibitor of red cell hexokinase (17).

Measurement of methemoglobin reduction rate in intact erythrocytes: Methemoglobin reduction was measured according to the method previously reported (18). Incubation conditions were as follows: An aliquot of the erythrocytes was treated with an equal volume of $1 \%$ sodium nitrite- $1 \%$ sodium chloride solution and was stirred for about $10 \mathrm{~min}$ at room temperature. The erythrocytes with methemoglobin were washed more than 7 times with $5-10$ volumes of saline solution in order to remove excess nitrite. The cells were suspended in 2 volumes of buffer $(100 \mathrm{mM} \mathrm{NaCl}, 30 \mathrm{mM}$ triethanolamine $-\mathrm{HCl}, 5 \mathrm{mM}$ phosphate, $\mathrm{pH}$ 7.4) and incubated at $37^{\circ} \mathrm{C}$ with $10 \mathrm{mM} \mathrm{KCl}, \mathrm{K}-\mathrm{GL}$ or glucose.

Statistical significance tests were performed using Student's $t$-test or an analysis of variance. A value of $P<0.05$ was accepted as indicating a significant difference.

\section{Results}

Uptake of $\mathrm{K}^{+}$into $\mathrm{Na}^{+}$-rich cells: Using $\mathrm{KCl}, \mathrm{Asp}-\mathrm{K}$ or $\mathrm{K}-\mathrm{GL}, \mathrm{K}^{+}$uptake into the $\mathrm{Na}^{+}-$ rich cells was examined. The relationship between the rate of transport and concentration of $\mathrm{KCl}$. Asp-K or K-GL (2-32 mM. external $\mathrm{K}^{+}$concentrations) is shown in Fig. 1. The $\mathrm{K}^{+}$transport was increased in an external $\mathrm{K}^{+}$concentration-dependent manner. At $8 \mathrm{mM}$ of external $\mathrm{K}^{+}$concentration, a significant difference in the $\mathrm{K}^{+}$uptake into the cells was observed between $K-G L$ and $\mathrm{KCl}(\mathrm{P}<0.05)$, but not between $\mathrm{K}-\mathrm{GL}$ and Asp- $\mathrm{K}$, and between Asp- $\mathrm{K}$ and $\mathrm{KCl}$. When external $\mathrm{K}^{+}$concentration was above $16 \mathrm{mM}$, there was a significant difference between $K-G L$ and Asp-K $(P<0.05)$. In the presence of $1 \times 10^{-4} \mathrm{M}$ ouabain, the increase in $\mathrm{K}^{+}$ transport caused by the three potassium salts was reduced markedly to the same level. This concentration of ouabain is known to inhibit $\mathrm{Na}^{+}, \mathrm{K}^{+}$-ATPase activity of $\mathrm{Na}^{+}$-rich erythrocyte membrane (19).

$\mathrm{Na}^{+}, \mathrm{K}^{+}$-ATPase activity of erythrocyte ghosts: Having suggested that $K-G L$ is the most effective substance for the $\mathrm{K}^{+}$uptake reaction among the three potassium salts examined and that potassium salts-induced

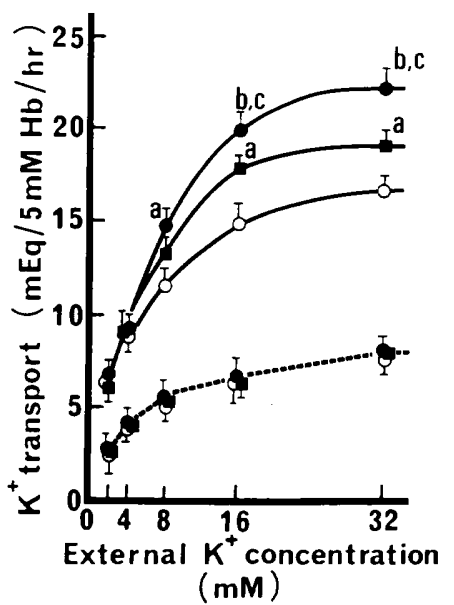

Fig. 1. Effect of $\mathrm{KCl}(\bigcirc)$, Asp-K ( $\square$ ) and K-GL (O) on $\mathrm{K}^{+}$uptake into $\mathrm{Na}^{+}$-rich erythrocytes with (--) or without (-) ouabain. Reaction conditions were 78-110 mM NaCl, $25 \mathrm{mM} \mathrm{Na}_{2} \mathrm{HPO}_{4}, 2 \mathrm{mM}$ $\mathrm{HCl}, 2 \mathrm{mM} \mathrm{MgCl}_{2}, 3.7 \mathrm{mM}$ inosine, $10 \mathrm{mM}$ glucose, $1 \mathrm{~g} / \mathrm{L}$ bovine albumin, $2-32 \mathrm{mM}$ of $\mathrm{KCl}$, Asp $-\mathrm{K}$ or $\mathrm{K}-\mathrm{GL}$, and $1 \times 10^{-4} \mathrm{M}$ ouabain. Each point represents the mean $(n=6-12)$ and the error bar, \pm 1 S.E.M. a,bSignificantly (a $P<0.05$; $\mathrm{bP}<0.01$ ) different from $\mathrm{KCl}$ at the same $\mathrm{K}^{+}$concentration, ${ }^{\mathrm{c}}$ significantly $(P<0.05)$ different from Asp- $K$ at the same $K^{+}$ concentration.

increase in $\mathrm{K}^{+}$transport is dependent on $\mathrm{Na}^{+}$. $\mathrm{K}^{+}$-ATPase activity, we next turned to the effect of potassium salts on the $\mathrm{Na}^{+}, \mathrm{K}^{+}$ATPase activity of the membrane fraction (ghost). Figure 2 shows the results of this study. The $\mathrm{Na}^{+}, \mathrm{K}^{+}$-ATPase activity was increased as the external $\mathrm{K}^{+}$concentration was increased, and the activity was independent of the form of potassium salt added in the medium. The smooth curve was drawn from the best-fitting Michaelis-Menten equation where the concentration of potassium at haif-maximal activity, $\mathrm{Km}$, is $2.2 \mathrm{mM} / \mathrm{L}$. This compares favorably with that reported by Post and jolly (10).

Lactate production and ATP content in intact erythrocytes: Figure 3 presents the concentration-dependent effect of potassium salts on lactate production rate in the cells. The effect of K-GL on lactate production was more potent than that of $\mathrm{KCl}$ or $\mathrm{Asp}-\mathrm{K}$, and there was a significant difference in lactate production between $\mathrm{K}-\mathrm{GL}$ and $\mathrm{Asp}-\mathrm{K}$ 
$(P<0.05)$, and $K-G L$ and $K C l(P<0.01)$ at $8 \mathrm{mM}$ of $\mathrm{K}^{+}$concentration. As can be seen in Table 1, $8 \mathrm{mM} \mathrm{K-GL}$ also significantly increased ATP content.

Effect of glycolysis inhibitors on K-GLinduced changes in $\mathrm{K}^{+}$, lactate and ATP content in $\mathrm{Na}^{+}$-rich cells: The effects of glycolysis inhibitors on K-GL-induced changes in lactate. ATP and $\mathrm{K}^{+}$content in $\mathrm{Na}^{+}$-rich cells were examined. The results of these experiments are shown in Fig. $4 . \mathrm{KCl}$ or $\mathrm{K}-\mathrm{GL}$ produced a significant increase in lactate, ATP and $\mathrm{K}^{+}$content, and these effects of K-GL were more potent than those of $\mathrm{KCl}$. In the case of lactate, the end product of glycolytic process, $10 \mathrm{mM}$ sodium fluoride $(\mathrm{NaF}), 1 \mathrm{mM}$ monoiodoacetate (MIA) or $1 \mathrm{mM}$ oxidized glutathione (GSSG) brought about a marked reduction in the content (Fig. 4A), indicating that these concentrations of the agents are effective

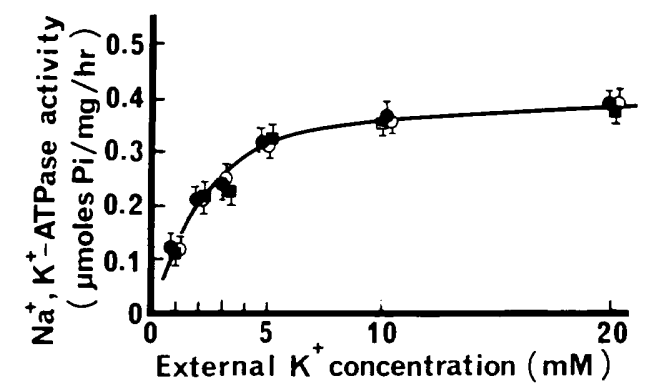

Fig. 2. Effect of $\mathrm{KCl}(\bigcirc)$. Asp-K (ם) and $\mathrm{K}-\mathrm{GL}$ (O) on $\mathrm{Na}^{+}, \mathrm{K}^{+}$-ATPase activity of hemoglobin-free ghosts. Reaction conditions were $3 \mathrm{mM}$ ATP, $5 \mathrm{mM}$ $\mathrm{MgCl}_{2}, 125-145 \mathrm{mM} \mathrm{NaCl}, 100 \mathrm{mM}$ Tris- $\mathrm{HCl}$, and $1-20 \mathrm{mM}$ of $\mathrm{KCl}$, Asp-K or K-GL. Each point represents the mean $(n=6-12)$ and the error bar. \pm 1 S.E.M. for inhibiting the glycolytic process in the present system. When these glycolysis inhibitors were present, the potassium salts had no effect on the lactate content (Fig. 4A). In contrast to the studies on lactate production, glycolysis inhibitors had little effect on the content of ATP (Fig. 4B) or $\mathrm{K}^{+}$ (Fig. 4C) in the non-treated or $\mathrm{KCl}$-treated group. However, K-GL-induced increase in ATP or $\mathrm{K}^{+}$content was significantly inhibited by NaF, MIA and by GSSG (Fig. 4, panels B and $\mathrm{C}$ ).

Methemoglobin reduction by K-GL: To determine the involvement of $\mathrm{K}-\mathrm{GL}$ in the pentose-phosphate pathway, the rate of

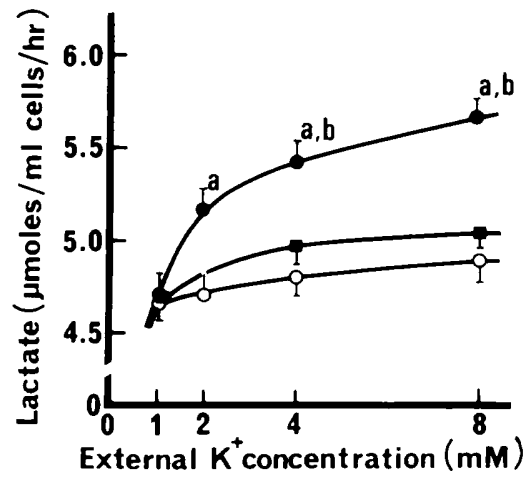

Fig. 3. Effect of $\mathrm{KCl}(\bigcirc)$, Asp-K ( $\square$ ) and K-GL (O) on lactate production of the intact erythrocytes. Reaction conditions were 112-119 mM NaCl, 25 $\mathrm{mM} \mathrm{Na}_{2} \mathrm{HPO}_{4}, 2 \mathrm{mM} \mathrm{HCl}, 10 \mathrm{mM}$ glucose, and $1-8 \mathrm{mM}$ of $\mathrm{KCl}$. Asp-K or K-GL. Each point represents the mean $(n=6-12)$ and the error bar, \pm 1 S.E.M. aSignificantly $(P<0.01)$ different from $\mathrm{KCl}$ at the same $\mathrm{K}^{+}$concentration, bsignificantly $(P<0.01)$ different from Asp-K at the same $K^{+}$ concentration.

Table 1. Effect of potassium salts on ATP content of intact erythrocytes*

\begin{tabular}{lcc}
\hline Treatment & $\mathrm{n}$ & $\begin{array}{c}\text { ATP content } \\
\text { (nmoles/ml cells) }\end{array}$ \\
None & 8 & $881 \pm 13.1$ \\
KCl & 8 & $919 \pm 9.8$ \\
Asp-K & 6 & $946 \pm 12.5^{\mathrm{a}}$ \\
K-GL & 8 & $985 \pm 8.7^{\mathrm{a}, \mathrm{b}, \mathrm{c}}$ \\
\hline
\end{tabular}

\footnotetext{
* Reaction conditions: $8 \mathrm{mM}$ of one of the potassium salts, $102 \mathrm{mM} \mathrm{NaCl}, 25 \mathrm{mM} \mathrm{Na}_{2} \mathrm{HPO}_{4}, 2 \mathrm{mM} \mathrm{HCl}$ and $10 \mathrm{mM}$ glucose, $\mathrm{pH} 7.4$, at $37^{\circ} \mathrm{C}$. All values are means $\pm S$.E.M. a Significantly $(P<0.01)$ different

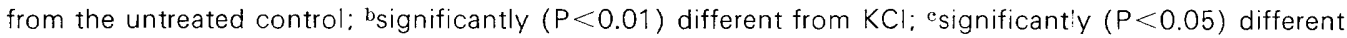
from Asp-K.
} 


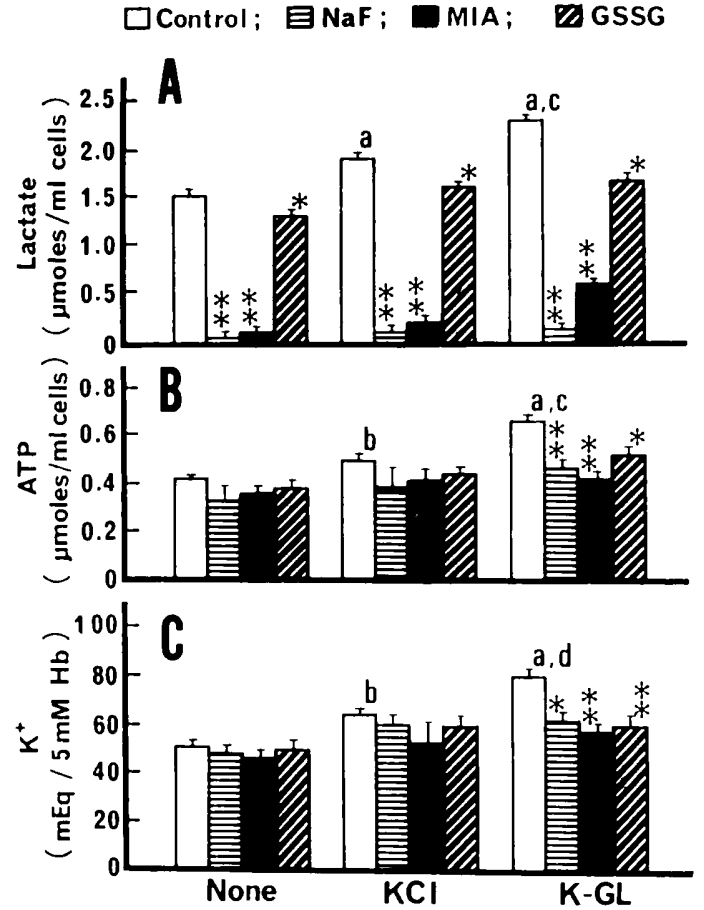

Fig. 4. Effect of sodium fluoride (NaF), monoiodoacetate (MIA) and oxidized glutathione (GSSG) in $\mathrm{Na}^{+}$-rich erythrocytes on $\mathrm{KCl}$ - or $\mathrm{K}-\mathrm{GL}$ induced changes in lactate (A). ATP (B) and in $\mathrm{K}^{+}$ content ( $C$ ). Reaction conditions of the studies presented in panels $A, B$, and $C$ were identical to those described in Fig. 3. Table 1, and Fig. 1, respectively, except that the final concentration of $\mathrm{KCl}$ or $\mathrm{K}-\mathrm{GL}$ was $16 \mathrm{mM}$, and $10 \mathrm{mM} \mathrm{NaF}, 1 \mathrm{mM}$ MIA or $1 \mathrm{mM}$ GSSG was included. Each column represents the mean $(n=6-9)$ and the error bar, \pm 1 S.E.M. a,bSignificantly a $\mathrm{P}<0.01$; b $\mathrm{P}<0.05$ ) different from the untreated control, "d, significantly c $P<0.01$ : $\left.{ }^{\mathrm{d}} \mathrm{P}<0.05\right)$ different from the $\mathrm{KCl}$ control. and ${ }^{*},{ }^{*}$ significantly $\left({ }^{*} P<0.05 ;{ }^{*} P<0.01\right)$ different from the control in each group.

methemoglobin reduction was investigated. The results (Fig. 5) show that when glucose was used as the substrate, the rate of methemoglobin reduction was more promoted than in the case of K-GL or $\mathrm{KCl}$. K-GL was a more effective potassium salt for the reaction than $\mathrm{KCl}$.

\section{Discussion}

It is well established that erythrocytes actively transport $\mathrm{K}^{+}$inwards and $\mathrm{Na}^{+}$

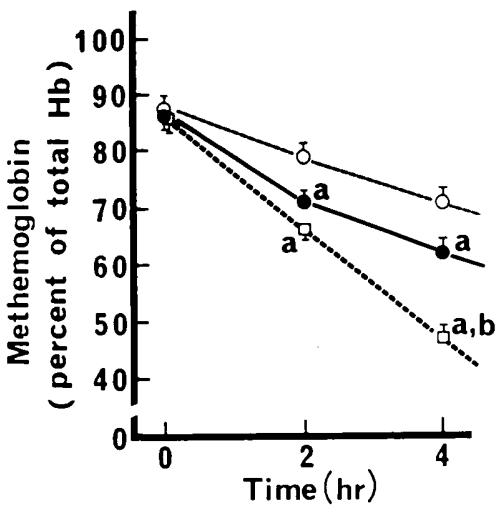

Fig. 5. Methemoglobin reduction by glucose ( $\square)$. $\mathrm{KCl}(\mathrm{O})$ and $\mathrm{K}-\mathrm{GL}(\mathrm{O})$ in intact erythrocytes. Reaction conditions: $100 \mathrm{mM} \mathrm{NaCl}, 30 \mathrm{mM}$ triethanolamine- $\mathrm{HCl}$, and $5 \mathrm{mM}$ phosphate. When added, the final concentration of glucose. $\mathrm{KCl}$ or $\mathrm{K}-\mathrm{GL}$ was $10 \mathrm{mM}$. Each point represents the mean $(n=5)$ and the error bar, \pm 1 S.E.M. "Significantly $(P<0.01)$ different from $\mathrm{KCl}$ at the same time. bsignificantly $(P<0.01)$ different from $K-G L$ at the same time.

outwards across their membrane against electrochemical potential gradients with energy from glycolysis (20). In the present study, potassium salts ( $\mathrm{KCl}, \mathrm{Asp}-\mathrm{K}, \mathrm{K}-\mathrm{GL}$ ) produced a marked increase in $\mathrm{K}^{+}$uptake into $\mathrm{Na}^{+}$-rich erythrocytes, and $\mathrm{K}-\mathrm{GL}$ was the most effective substance for the uptake among the three potassium salts examined. In the presence of ouabain, the increases in $\mathrm{K}^{+}$uptake caused by these three potassium salts were diminished markedly to the same level (Fig. 1), suggesting that the increase in the active $\mathrm{K}^{+}$transport induced by $\mathrm{K}-\mathrm{GL}$ as well as other potassium salts may be $\mathrm{Na}^{+}, \mathrm{K}^{+}$. ATPase dependent. However, when the experiment was carried out in hemoglobinfree ghosts without a glycolytic system, there was no significant difference in the stimulatory effects of K-GL and other potassium salts on $\mathrm{Na}^{+}, \mathrm{K}^{+}$-ATPase activity (Fig. 2). This may be due to the absence of cytoplasma which participates in the glycolytic metabolism of erythrocytes.

If the $\mathrm{K}-\mathrm{GL}$ induced increase in $\mathrm{K}^{+}$transport into erythrocytes is mediated by acceleration of the glycolytic process, the effect of K-GL on the $\mathrm{K}^{+}$transport should be inhibited by 
glycolysis inhibitors. We therefore tested this hypothesis by application of glycolysis inhibitors to our experimental system. When the enzyme systems of the phosphoglyceratephosphopyruvate stages were inhibited by sodium fluoride, when the cycle between 3 phosphoglyceraldehyde and 1,3-diphosphoglycerate was stopped by monoiodoacetate and when hexokinase, a rate-limiting enzyme of the reaction of erythrocyte glycolysis, was inhibited by oxidized glutathione, $\mathrm{K}-\mathrm{GL}$-induced increase in $\mathrm{K}^{+}$content was abolished (Fig. 4C). These results are consistent with the view that K-GL, through acceleration of the glycolytic process, may be able to enhance active $\mathrm{K}^{+}$transport of erythrocytes.

It is known that the pentose-phosphate pathway is a cyclic pathway which leads from glucose 6-phosphate and eventually produces fructose 6 -phosphate and glyceraldehyde 3-phosphate, both of which are intermediates in the main pathway of glycolysis. Furthermore, gluconate is a substrate of the pentose-phosphate pathway (21). and it is known to be converted into xylulose. an efficient reductant of methemoglobin in human erythrocytes (18). In the present experiments, K-GL was also an effective potassium salt for the methemoglobin reduction as shown in Fig. 5. This may suggest the possibility that K-GL provides gluconate, a substrate of the pentose-phosphate pathway, and the pathway is an active participant in the effect of $\mathrm{K}-\mathrm{GL}$ on active $\mathrm{K}^{+}$ transport into erythrocytes.

In conclusion, it would appear that K-GL enhances active $\mathrm{K}^{+}$transport of erythrocytes by the increased ATP production, an energy source of $\mathrm{Na}^{+}, \mathrm{K}^{+}$-ATPase, via glycolytic process as well as the increased external $\mathrm{K}^{+}$ concentration.

Acknowledgements: $\mathrm{K}-\mathrm{GL}$ and Asp-K were kindly supplied by the Kayaku Co., Saitama, Japan.

\section{References}

1 Frohlich, E.D.: Use and abuse of diuretics. Am. Heart J. 89, 1-3 (1975)

2 Ghione, S., Clerico, A., Fommei, E., Cocci, F., Bartolomei, C. and Riccioni, N.: Hypertension and hypokalemia caused by $9 \alpha$-fluoroprednisolone in a nasal spray. Lancet 1, 1301 (1979)
3 Sandøe, E. and Olesen, K.: Hypokalaemia, hypochloraemia and baseosis in long-term treatment of oedematous heart failure with benzothiadiazine diuretics. Acta Med. Scand. 172, 691-697 (1962)

4 Manner, R.J., Brechbill, D.O. and Dewitt, K.: Prevalence of hypokalemia in diuretic therapy. Clin. Med. 79, 15-18 (1972)

5 Ito, H., Matsukawa, H., Odagiri, M., Watanabe, T. and Itakura, Y.: Pharmacological studies on potassium gluconate. (1) General pharmacology of potassium gluconate. Clinical Report 6, 788809 (1972) (in Japanese)

6 Ueda, T., Ogura, Y., Kawaguchi, Y., Sakai, S., Yamamoto, M., Kimura, Y., Oda, Y., Tanaka, S., Sekiguchi, C.. Takasu, T., Urakabe, S., Orita, Y., Ueda, N., Tojo, S., Tsuchiya, N., Watanabe, K., Suzuki, H., Ajiro, K., Ito, H. and Hara, A.: Clinical assessment of potassium gluconate on hypokalemia by double-blind test. Clinical Report 8 , 3590-3611 (1974) (in Japanese)

7 Harris, J.E.: The influence of the metabolism of human erythrocytes on their potassium content. J. Biol. Chem. 141, 579-595 (1941)

8 Danowski, T.S.: The transfer of potassium across the human blood cell membrane. J. Biol. Chem. 139, 693-705 (1941)

9 Prankerd, T.A.J.: Metabolism of the human erythrocyte: a review. Br. J. Haematol. 1, 131145 (1955)

10 Post, R.L. and Jolly, P.C.: The linkage of sodium, potassium, and ammonium active transport across the human erythrocyte membrane. Biochim. Biophys. Acta 25, 118-128 (1957)

11 Zijlstra, W.G. and Van Kampen, E.J.: Standardization of hemoglobinometry. I. The extinction coefficient of hemoglobin cyanide. Clin. Chim. Acta 5, 719-26 (1960)

12 Dodge, J.T., Mitchell. C. and Hanahan, D.J.: The preparation and chemical characteristics of hemoglobin-free ghosts of human erythrocytes. Arch. Biochem. Biophys. 100, 119-130 (1963)

13 Dryer, R.L., Tammes, A.R. and Routh, J.I.: The determination of phosphorus and phosphatase with $\mathrm{N}$-phenyl-p-phenylenediamine. J. Biol. Chem. 225, 177-183 (1957)

14 Lowry, O.H., Rosebrough, N.J., Farr, A.L. and Randall, R.J.: Protein measurement with the Folin phenol reagent. J. Biol. Chem. 193, 265275 (1951)

15 Minakami, S., Suzuki, C., Saito, T. and Yoshikawa, H.: Studies on erythrocyte glycolysis. I. Determination of the glycolytic intermediates in human erythrocytes. J. Biochem. (Tokyo) 58, 
543-550 (1965)

16 Montague, M.: Factors in the active transport of cations. J. Physiol. (Lond.) 112, 59-83 (1951)

17 Magnani, M., Stocchi, V., Ninfali, P., Dacha, M. and Fornaini, G.: Action of oxidized and reduced glutathione on rabbit red blood cell hexokinase. Biochim. Biophys. Acta 615, 113-120 (1980)

18 Asakura, T., Adachi, K., Minakami, S. and Yoshikawa, H.: Non-glycolytic sugar metabolism in human erythrocytes. I. Xylitol metabolism. J. Biochem. (Tokyo) 62, 184-193 (1967)
19 Post, R.L., Merritt, C.R., Kinsolving, C.R. and Albright, C.D.: Membrane adenosine triphosphatase as a participant in the active transport of sodium and potassium in the human erythrocyte. J. Biol. Chem. 235, 1796-1802 (1960)

20 Whittam, R.: Potassium movements and ATP in human red cells. J. Physiol. (Lond.) 140, 479-497 (1958)

21 Grimes, A.J.: Human Red Cell Metabolism. p. 192-201. Blackwell, Oxford (1980) 